\title{
Desulfotomaculum thermocisternum sp. nov., a Sulfate Reducer Isolated from a Hot North Sea Oil Reservoir
}

\author{
ROALD KÅRE NILSEN, ${ }^{*}$ TERJE TORSVIK, AND TORLEIV LIEN \\ Department of Microbiology, University of Bergen, N-5020 Bergen, Norway
}

\begin{abstract}
The organism described in this paper, strain $S T 90^{\mathrm{T}}$ ( $\mathrm{T}=$ type strain), is a thermophilic, spore-forming, rod-shaped sulfate reducer that was isolated from North Sea oil reservoir formation water. In cultivation the following substances were used as electron donors and carbon sources: $\mathrm{H}_{2}-\mathrm{CO}_{2}$, lactate, pyruvate, ethanol, propanol, butanol, and $\mathrm{C}_{3}$ to $\mathrm{C}_{10}$ and $\mathrm{C}_{14}$ to $\mathrm{C}_{17}$ carboxylic acids. Sulfate was used as the electron acceptor in these reactions. Lactate was incompletely oxidized. Sulfite and thiosulfate were also used as electron acceptors. In the absence of an electron acceptor, the organism grew syntrophically on propionate together with a hydrogenothrophic methanogen. The optimum conditions for growth on lactate and sulfate were $62^{\circ} \mathrm{C}, \mathrm{pH} 6.7$, and 50 to $200 \mathrm{mM} \mathrm{NaCl}$. The G+C content was $56 \mathrm{~mol} \%$, as determined by high-performance liquid chromatography and $57 \mathrm{~mol} \%$ as determined by thermal denaturation. Spore formation was observed when the organism was grown on butyrate or propanol as a substrate and at low $\mathrm{pH}$ values. On the basis of differences in $\mathrm{G}+\mathrm{C}$ content and phenotypic and immunological characteristics when the organism was compared with other thermophilic Desulfotomaculum species, we propose that strain $\mathrm{ST}^{\mathrm{T}}{ }^{\mathrm{T}}$ is a member of a new species, Desulfotomaculum thermocisternum. D. thermocisternum can be quickly identified and distinguished from closely related Desulfotomaculum species by immunoblotting.
\end{abstract}

The genus Desulfotomaculum comprises a heterogeneous group of gram-positive, spore-forming sulfate reducers that includes both mesophilic and thermophilic species. The following seven thermophilic species have been validly described previously: Desulfotomaculum nigrificans, which was isolated from canned food (52) and produced oil field water $(1,30)$; Desulfotomaculum geothermicum, Desulfotomaculum australicum, and Desulfotomaculum kuznetsovii, which were isolated from geothermal groundwater $(13,26,29)$ (D. kuznetsovii has also been isolated from cold marine sediment [18]); Desulfotomaculum thermoacetoxidans and Desulfotomaculum thermobenzoicum, which were isolated from thermophilic fermentation reactors $(28,48)$; and Desulfotomaculum thermosapovorans, which was isolated from compost (16). Workers have also described several thermophilic Desulfotomaculum strains whose phylogenetic positions within the genus have not been determined $(20,39,47)$.

North Sea oil field reservoirs are hot marine habitats that are 1.2 to $6 \mathrm{~km}$ below the seafloor; the pressures in these habitats range from 50 to $80 \mathrm{MPa}$, and the temperatures range from 60 to $200^{\circ} \mathrm{C}$. The concentration of sulfate is usually between 0 and $0.6 \mathrm{mM}$ and varies from one reservoir to another. Aliphatic carboxylic acids are the most abundant organic acids in petroleum reservoirs. In North Sea formation water, acetic acid is found at concentrations up to $20 \mathrm{mM}$, with decreasing concentrations of higher homologs up to octanoic acid $(2,5)$. These acids are potential electron donors for sulfate reduction. Formic acid is usually not detected (24). During offshore oil production, anaerobic seawater is injected into the reservoirs to enhance oil recovery.

A large number of thermophilic sulfate reducers have been isolated from produced oil field waters $(1,3,4,8,9,30,37,39$, $40,45)$. Biogenic production of $\mathrm{H}_{2} \mathrm{~S}$ causes corrosion of iron and steel alloys in oil wells and in oil-processing systems on the

\footnotetext{
* Corresponding author. Present address: Department of Engineering, Stord/Haugesund College, Skåregt. 103, N-5500 Haugesund, Norway. Phone: 47-52702661. Fax: 47-52702700. Electronic mail address: RKN@tommy.ssh.no.
}

platforms. Bacterial plugging $(12,38)$ and precipitation of sulfides in an oil reservoir may also reduce the permeability of oil formation $\left(1,11,32\right.$ ). Exposure of oil field workers to $\mathrm{H}_{2} \mathrm{~S}$ represents a health hazard $(21,49)$.

In this paper we describe a new thermophilic, spore-forming sulfate reducer. The strain which we describe (strain ST $90^{\mathrm{T}}[\mathrm{T}$ $=$ type strain]) was isolated from a Statfjord oil field reservoir water sample. The sample was obtained before the breakthrough of injection water and consisted of pure formation water. Because of significant differences in $\mathrm{G}+\mathrm{C}$ contents and physiological and immunological properties between strain ST $90^{\mathbf{T}}$ and other thermophilic members of the genus Desulfotomaculum, we propose that strain $\mathrm{ST} 90^{\mathrm{T}}$ should be placed in a new species, Desulfotomaculum thermocisternum.

\section{MATERIALS AND METHODS}

Isolation and cultivation. Thermophilic sulfate reducers were enriched from oil field water separated from crude oil. The sample which we used was collected from a wellhead on the Statfjord A platform in the Norwegian sector of the North Sea. The water originated from the Brent group formation $2.6 \mathrm{~km}$ below the sea floor, where the temperature was $90^{\circ} \mathrm{C}$ and the pressure was $30 \mathrm{MPa}$. The concentration of sulfate in the Brent Group formation water was less than 0.16 $\mathrm{mM}$. The total organic acid concentration was about $20 \mathrm{mM}$, and acetic acid was the most abundant organic acid (the concentration of acetic acid was up to 18 $\mathrm{mM})(2)$. The sample was obtained before seawater (injection water) breakthrough and consisted of $100 \%$ pure formation water. The temperature at the sampling point was $65^{\circ} \mathrm{C}$. The in situ $\mathrm{pH}$ of the Statfjord reservoir has been estimated to be between 5.0 and 5.5. The $\mathrm{pH}$ of the sample after pressure release was 7.8 .

For enrichment, 5-ml water samples were added to $50-\mathrm{ml}$ portions of the marine medium described by Widdel and Pfennig (54). Then $1 \mathrm{ml}$ of trace element solution SL-10 (53) per liter of medium and $5 \mathrm{ml}$ of vitamin solution (34) per liter of medium were added. The $\mathrm{pH}$ was adjusted to 7.1 with $\mathrm{HCl}$ or $\mathrm{Na}_{2} \mathrm{CO}_{3}$. Lactate (final concentration, $20 \mathrm{mM}$ ) was added to the medium from a sterile anoxic stock solution.

Pure cultures were isolated in a dilution series by using the shake tube culture method (55); anoxic Gelrite gellan gum (Kelco Div., Merck and Co., San Diego, Calif.) was used as the gelling agent, and the cultures were incubated at $60^{\circ} \mathrm{C}$ with lactate as the substrate.

The growth medium used in this study was the medium described by Beeder et al. (4) except that sodium acetate was omitted. All growth experiments were carried out at $60^{\circ} \mathrm{C}$ and atmospheric pressure, unless indicated otherwise. Strain ST90 ${ }^{\mathrm{T}}$ was also grown in coculture with Methanococcus thermolithotrophicus ST22 (= DSM 8766) at $60^{\circ} \mathrm{C}$; the medium used was the medium described 
TABLE 1. Properties of Desulfotomaculum species and strains T93B and $\mathrm{ST}^{\mathrm{T}} \mathrm{0}^{\mathrm{T} a}$

\begin{tabular}{|c|c|c|c|c|c|c|c|c|c|}
\hline Characteristic & D. nigrificans & $\begin{array}{l}\text { D. geother- } \\
\text { micum }\end{array}$ & $\begin{array}{l}\text { D. kuznet- } \\
\text { sovii }\end{array}$ & $\begin{array}{l}\text { D. thermoace- } \\
\text { toxidans }\end{array}$ & $\begin{array}{l}\text { D. thermo- } \\
\text { benzoicum }\end{array}$ & $\begin{array}{l}\text { D. thermo- } \\
\text { sapovorans }\end{array}$ & D. australicum & Strain $\mathrm{T} 3 \mathrm{~B}^{b}$ & Strain $\mathrm{ST} 90^{\mathrm{T}}$ \\
\hline \multicolumn{10}{|l|}{$\mathrm{e}^{-}$donors $^{d}$} \\
\hline $\mathrm{H}_{2}{ }^{e}$ & $+^{f}$ & $+^{f}$ & + & + & + & + & + & + & + \\
\hline Formate $(10 \mathrm{mM})$ & $+^{f}$ & $+^{\prime}$ & + & + & + & + & - & + & - \\
\hline Acetate $(20 \mathrm{mM})$ & - & - & + & + & - & - & + & + & - \\
\hline Propionate $(10 \mathrm{mM})$ & - & + & + & + & + & - & - & + & + \\
\hline Pyruvate $(10 \mathrm{mM})$ & + & $\mathrm{NT}^{\mathrm{g}}$ & + & + & + & + & + & + & + \\
\hline Lactate $(20 \mathrm{mM})$ & + & + & + & + & + & + & + & + & + \\
\hline Butyrate $(10 \mathrm{mM})$ & - & + & + & + & + & + & - & + & + \\
\hline Isobutyrate $(10 \mathrm{mM})$ & NT & NT & NT & NT & NT & - & NT & NT & - \\
\hline Pentanoate $(10 \mathrm{mM})$ & NT & NT & + & + & + & + & NT & + & + \\
\hline Hexanoate $(10 \mathrm{mM})$ & NT & + & + & + & + & + & NT & + & + \\
\hline Heptanoate $(10 \mathrm{mM})$ & NT & - & NT & NT & NT & + & NT & NT & + \\
\hline Octanoate $(2.5 \mathrm{mM})$ & NT & + & + & + & NT & + & NT & + & + \\
\hline Nonanoate $(0.5 \mathrm{mM})$ & NT & + & NT & NT & NT & + & NT & NT & + \\
\hline Decanoate $(0.5 \mathrm{mM})$ & NT & - & NT & NT & NT & + & NT & NT & + \\
\hline Dodecanoate $(0.5 \mathrm{mM})$ & NT & NT & NT & NT & NT & + & NT & NT & - \\
\hline Hexadecanoate $(1 \mathrm{mM})$ & NT & + & + & - & NT & + & NT & NT & + \\
\hline Octadecanoate $(0.5 \mathrm{mM})$ & NT & + & NT & NT & NT & + & NT & NT & - \\
\hline Methanol $(30 \mathrm{mM})$ & - & - & + & NT & - & + & - & + & - \\
\hline Ethanol $(20 \mathrm{mM})$ & + & + & + & - & + & + & + & + & + \\
\hline Propanol $(20 \mathrm{mM})$ & $+f$ & NT & + & + & + & + & NT & + & + \\
\hline Butanol $(20 \mathrm{mM})$ & $+^{f}$ & NT & + & + & + & + & NT & + & + \\
\hline Benzoate (5 mM) & - & - & - & - & + & - & + & - & - \\
\hline Phenylacetate $(10 \mathrm{mM})$ & NT & NT & NT & NT & NT & NT & NT & NT & - \\
\hline Fructose $(4 \mathrm{mM})$ & + & + & - & NT & - & - & NT & - & - \\
\hline \multicolumn{10}{|l|}{$\mathrm{e}^{-}$acceptors } \\
\hline $\mathrm{SO}_{3}^{2-}$ & + & + & + & - & + & + & NT & + & + \\
\hline $\mathrm{S}_{2} \mathrm{O}_{3}^{2-}$ & + & NT & + & + & + & + & NT & + & + \\
\hline $\mathrm{S}^{0}$ & - & - & - & - & - & - & NT & NT & - \\
\hline $\mathrm{NO}_{3}^{-}$ & - & - & - & - & + & NT & NT & - & - \\
\hline Temp range $\left({ }^{\circ} \mathrm{C}\right)$ & $30-70$ & $30-57$ & $50-85$ & $45-65$ & $40-70$ & $35-60$ & $40-74$ & $43-78$ & $41-75$ \\
\hline Optimum temp $\left({ }^{\circ} \mathrm{C}\right)$ & 55 & 54 & $60-65$ & $55-60$ & 62 & 50 & 68 & 65 & 62 \\
\hline $\mathrm{pH}$ range & NT & $6.0-8.0$ & NT & $6.0-7.5$ & $6.0-8.0$ & NT & $5.5-8.5$ & $6.7-7.5$ & $6.2-8.9$ \\
\hline Optimum pH & NT & $7.2-7.4$ & NT & 6.5 & 7.2 & $7.2-7.5$ & $7.0-7.4$ & 7.0 & 6.7 \\
\hline $\mathrm{NaCl}$ concn range $(\mathrm{mM})$ & $0-\mathrm{NT}$ & $34-860$ & $0-510$ & $0-260$ & $0-\mathrm{NT}$ & $0-600$ & NT & $0-1,200$ & $0-800$ \\
\hline Optimum $\mathrm{NaCl}$ conen $(\mathrm{mM})$ & NT & $410-580$ & 0 & 0 & NT & 260 & NT & NT & $50-200$ \\
\hline $\mathrm{G}+\mathrm{C}$ content $(\mathrm{mol} \%)$ & $48-50$ & 50 & 49 & 50 & 53 & 51 & 48 & 51 & $56(57)$ \\
\hline
\end{tabular}

${ }^{a}$ Data from references $7,13,16,22,25,27,28$, and 47 unless indicated otherwise.

${ }^{b}$ Data from reference 39 .

${ }^{c}$ Data from this study.

${ }^{d}$ The concentrations in parentheses are the concentrations used in experiments with strain ST $90^{\mathrm{T}}$.

${ }^{e}$ Strain $\mathrm{ST} 90^{\mathrm{T}}$ was grown in the presence of $\mathrm{H}_{2}-\mathrm{CO}_{2}(80: 20$, vol/vol; $0.2 \mathrm{MPa})$.

${ }^{f}$ In the presence of $1 \mathrm{mM}$ acetate.

${ }^{g}$ NT, not tested.

previously (4), except that sodium acetate and $\mathrm{Na}_{2} \mathrm{SO}_{4}$ were omitted and propionate was the sole carbon and energy source.

D. kuznetsovii VKM B-1805 $\left(=\mathrm{DSM} 6115^{\mathrm{T}}\right)$ was grown at $60^{\circ} \mathrm{C}$ in a medium containing (per liter) $4.00 \mathrm{~g}$ of $\mathrm{NaCl}, 12.50 \mathrm{~g}$ of $\mathrm{MgSO}_{4} \cdot 7 \mathrm{H}_{2} \mathrm{O}, 0.50 \mathrm{~g}$ of $\mathrm{CaCl}_{2} \cdot 2 \mathrm{H}_{2} \mathrm{O}, 2.00 \mathrm{~g}$ of $\left(\mathrm{NH}_{4}\right)_{2} \mathrm{SO}_{4}, 1.40 \mathrm{~g}$ of $\mathrm{K}_{2} \mathrm{HPO}_{4} \cdot 3 \mathrm{H}_{2} \mathrm{O}, 0.40 \mathrm{~g}$ of KCl, 2 $\mathrm{mg}$ of $\mathrm{Fe}\left(\mathrm{NH}_{4}\right)_{2}\left(\mathrm{SO}_{4}\right)_{2} \cdot 3 \mathrm{H}_{2} \mathrm{O}, 1 \mathrm{mg}$ of resazurin, $1.00 \mathrm{~g}$ of yeast extract (Difco Laboratories), $5.00 \mathrm{~g}$ of $\mathrm{NaHCO}_{3}, 0.50 \mathrm{~g}$ of $\mathrm{Na}_{2} \mathrm{~S} \cdot 9 \mathrm{H}_{2} \mathrm{O}, 10 \mathrm{ml}$ of a trace element solution (56), $5 \mathrm{ml}$ of a vitamin solution (34), and $5.0 \mathrm{~g}$ of lactate (sodium salt). D. thermobenzoicum $\operatorname{TSB}^{\mathrm{T}}$ (= DSM $6193^{\mathrm{T}}$ ) and $D$. australicum $\mathrm{AB} 33^{\mathrm{T}}$ ( $=\mathrm{ACM} 3917^{\mathrm{T}}$ ) were grown in medium $\mathrm{G}(35)$ containing lactate as the carbon and energy source at 50 and $60^{\circ} \mathrm{C}$, respectively.

Chemical and other determinations. Grids coated with Formvar-carbon (Balzers AG) and rendered hydrophilic by glow discharge were used for negative staining with $1 \%(\mathrm{wt} / \mathrm{vol})$ uranyl acetate $(\mathrm{pH} 4.2)$. For transmission electron micrographs cells were fixed with glutaraldehyde and embedded in Spurr lowviscosity resin (43) as described by Walther-Mauruschat et al. (51). Thin sections were contrasted with uranyl acetate $(3 \%)$ and lead citrate. The preparations were examined with a JEOL model $100 \mathrm{~S}$ electron microscope. The concentration of hydrogen sulfide was determined by using copper sulfate (10). Acetate was assayed as described previously (3). The amount of methane in the gas phase was determined as described previously (31)

Preparation of anti-ST90 ${ }^{\mathrm{T}}$. Cells were preserved in $2 \%$ (vol/ $\left./ \mathrm{vol}\right)$ formaldehyde and washed twice in phosphate-buffered saline $(8.50 \mathrm{~g}$ of $\mathrm{NaCl}$ per liter, $1.44 \mathrm{~g}$ of $\mathrm{Na}_{2} \mathrm{HPO}_{4} \cdot 2 \mathrm{H}_{2} \mathrm{O}$ per liter, $0.25 \mathrm{~g}$ of $\mathrm{KH}_{2} \mathrm{PO}_{4}$ per liter; $\mathrm{pH}$ 7.2). Polyclonal antiserum against strain $\mathrm{ST} 90^{\mathrm{T}}$ (anti-ST90 ${ }^{\mathrm{T}}$ ) was produced as described previously (8).

Serological test. Antigens were characterized by performing a Western blot (immunoblot) analysis of whole-cell extracts that had been solubilized with sodium dodecyl sulfate (SDS). Polyacrylamide gel electrophoresis (PAGE) of the whole-cell extracts was carried out as described by Laemmli (23). Electrophoresis was performed at $190 \mathrm{~V}$ by using a Mini Protean II dual-slab cell (Bio-Rad Laboratories, Richmond, Calif.). After electrophoresis the gels were stained with Coomassie brilliant blue R-250 (Serva). Unstained gels were immunoblotted as described by Burnette (6) by using a Mini Trans Blot cell (Bio-Rad).

$16 S$ rDNA analysis. DNA extraction, PCR-mediated amplification of the $16 \mathrm{~S}$ ribosomal DNA (rDNA), and purification of PCR products were carried out as described previously (36). Purified PCR products were sequenced by using a Taq DyeDeoxy terminator cycle sequencing kit (Applied Biosystems, Foster City, Calif.) as recommended by the manufacturer. An Applied Biosystems model 373A DNA sequencer was used to electrophorese the sequence reaction products. The 16S rDNA sequences were aligned manually with the sequences of representative gram-positive bacteria. The sequence of D. kuznetsovii was not available. Pairwise evolutionary distances were computed by using the correction of Jukes and Cantor (19). The least-squares distance method of DeSoete (15) was used to construct a phylogenetic dendrogram from distance matrix data. The 16S rDNA analysis was performed by F. A. Rainey at the Deutsche Sammlung von Mikroorganismen und Zellkulturen GmbH, Braunschweig, Germany.

DNA analysis. The $\mathrm{G}+\mathrm{C}$ content was determined by both a thermal denatur- 
ation method (14) and a chemical method in which high-performance liquid chromatography (HPLC) $(27,46)$ was used to separate the nucleotides. The DNA samples used for the thermal denaturation method and for the chemical method were extracted and purified as described by Silhavy et al. $(41,42)$ and Visuvanathan et al. (50), respectively. The determination of $G+C$ content by the chemical method was performed at the Deutsche Sammlung von Mikroorganismen und Zellkulturen GmbH.

Storage. For long-term preservation $0.9 \mathrm{ml}$ of a culture in the mid-exponential growth phase and $0.9 \mathrm{ml}$ of anoxic glycerol medium ( $80 \%$ growth medium, $20 \%$ glycerol) were transferred to a screw-cap plastic vial (Cryo-tube). A crystal of dithionite was added, and the vial was capped and stored at $-80^{\circ} \mathrm{C}$. Strain ST $90^{\top}$ has been stored in this way for more than 4 years.

Nucleotide sequence accession number. The 16S rDNA sequences of strains ST $90^{\mathrm{T}}$ and T93B have been deposited in the GenBank database under accession numbers U33455 and U33456, respectively.

\section{RESULTS}

Enrichment and isolation. Pure formation water from the Statfjord oil field was used as the inoculum for enrichment of thermophilic sulfate reducers, and lactate was used as the substrate. Smooth, pale yellow, discus-shaped colonies were observed in Gelrite gellan gum after 7 days of incubation at $60^{\circ} \mathrm{C}$. A pure culture, which was designated strain ST $90^{\mathrm{T}}$, became dense after 2 days of incubation at $60^{\circ} \mathrm{C}$ in growth medium containing lactate as the substrate. This isolate has been deposited in the Deutsche Sammlung von Mikroorganismen und Zellkulturen GmbH as strain DSM $10259^{\mathrm{T}}$.

Cell morphology. The cells of strain $S T 90^{\mathrm{T}}$ were straight rods that occurred singly and in chains. The cell diameter ranged from 0.7 to $1.0 \mu \mathrm{m}$, and the cell length ranged from 2.0 to $5.2 \mu \mathrm{m}$. Cells of different sizes were observed in the same chain. Single cells were motile and had peritrichous flagella. Spores were spherical and central and distended the cells to a diameter of $1.7 \mu \mathrm{m}$. No gas vacuoles were observed. Transmission electron micrographs revealed a cell wall structure characteristic of gram-positive bacteria (not shown).

Growth and nutritional properties. We examined the ability of strain ST90 ${ }^{\mathrm{T}}$ to use different electron donors and acceptors. In addition to the results shown in Table 1, the following results were obtained: tetradecanoate $(10 \mathrm{mM})$, pentadecanoate $(0.5 \mathrm{mM})$, and heptadecanoate $(1 \mathrm{mM})$ were utilized as carbon and energy sources, while undecanoate $(0.5 \mathrm{mM})$, tridecanoate $(0.5 \mathrm{mM}), n$-dodecane, $n$-tetradecane, and crude oil were not utilized. The presence of crude oil did not inhibit growth on lactate and sulfate. Biotin was required as a growth factor.

When grown on lactate and sulfate, strain $\mathrm{ST} 90^{\mathrm{T}}$ produced stoichiometric amounts of acetate, showing that the isolate oxidized this substrate incompletely. When lactate, propanol, or heptadecanoate was used as the substrate, strain ST $90^{\mathrm{T}}$ grew in the presence of sulfide concentrations up to $9 \mathrm{mM}$. Spore formation was observed when butyrate and propanol were used as substrates. Fermentative growth was observed on pyruvate in the absence of any electron acceptor. In sulfatefree medium strain $\mathrm{ST} 90^{\mathrm{T}}$ grew on propionate in a coculture with a hydrogenotrophic methanogen that produced methane.

Strain $\mathrm{ST} 90^{\mathrm{T}}$ grew at temperatures between 41 and $75^{\circ} \mathrm{C}$, and optimal growth occurred at $62^{\circ} \mathrm{C}$; no growth was observed at 37 or $77^{\circ} \mathrm{C}$. Growth occurred at initial $\mathrm{pH}$ values between 6.2 and 8.9 , and the optimum $\mathrm{pH}$ was 6.7 . Spore formation was observed when the initial $\mathrm{pH}$ was 6.2 but not under more alkaline conditions. Growth was observed in medium containing $17 \mu \mathrm{M}$ to $800 \mathrm{mM} \mathrm{NaCl}$, and optimum growth occurred in the presence of 50 to $200 \mathrm{mM} \mathrm{NaCl}$. $\mathrm{NaCl}$ concentrations lower than $17 \mu \mathrm{M}$ were not tested. No growth occurred in the presence of $900 \mathrm{mM} \mathrm{NaCl}$.

Whole-cell protein profile. SDS-PAGE revealed notable differences in the protein profiles of $D$. thermobenzoicum, $D$.
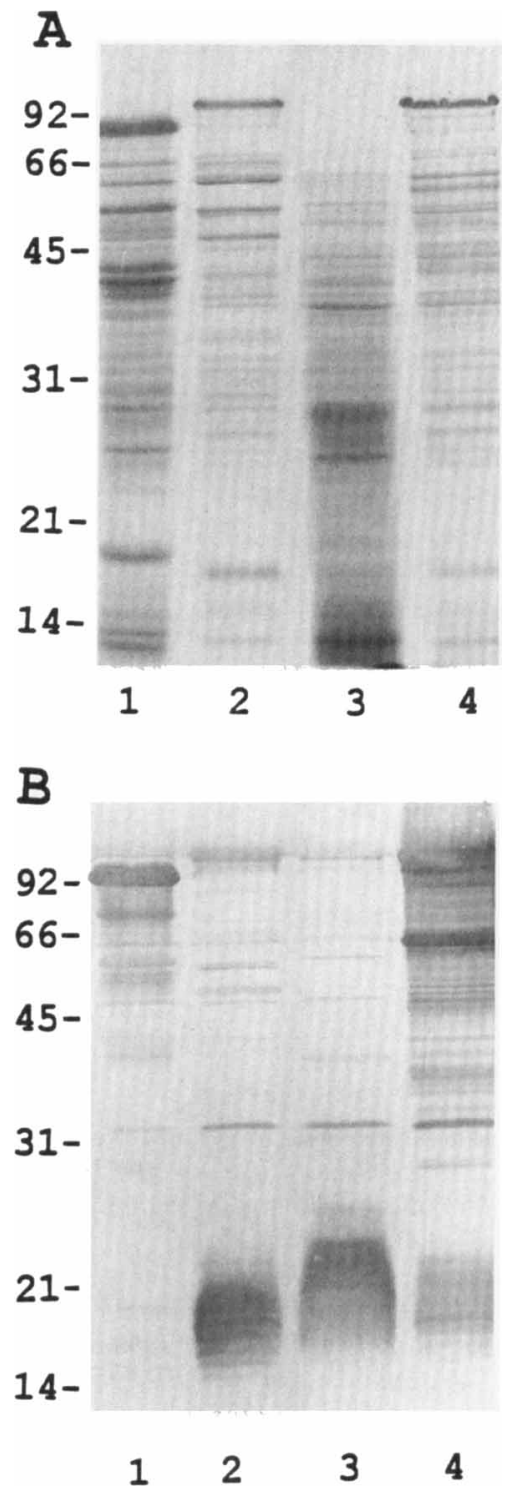

FIG. 1. Protein patterns (A) and immunoblots obtained with anti-ST90 ${ }^{\mathrm{T}}$ (B) after SDS-PAGE of SDS-soluble whole-cell extracts of $D$. thermobenzoicum (lanes 1), D. australicum (lanes 2), D. kuznetsovii (lanes 3), and strain ST90 ${ }^{\mathrm{T}}$ (lanes 4). The positions of molecular mass standards (in kilodaltons) are indicated on the left.

australicum, D. kuznetsovii, and strain ST90 ${ }^{\mathrm{T}}$ (Fig. 1A). Prominent bands at molecular weights of 64,000 and 59,000 were unique to strain $\mathrm{ST} 90^{\mathrm{T}}$. D. kuznetsovii produced a protein profile that was quite different from the protein profiles of the other strains tested, especially in the molecular weight range from 45,000 to 100,000 .

Serological characterization. Immunoblots of the whole-cell protein profiles of $D$. thermobenzoicum, $D$. australicum, and $D$. kuznetsovii were compared with an immunoblot of strain ST $90^{\mathrm{T}}$ obtained by using anti-ST90 ${ }^{\mathrm{T}}$ (Fig. 1B). A number of differences in the antigen profiles of these organisms were evident, and several antigens were unique to strain $\mathrm{ST} 90^{\mathrm{T}} . D$. thermobenzoicum and $D$. australicum had antigens in common with strain ST90 at molecular weights of 34,000 to 104,000 and 15,000 to 23,000 , respectively. Anti-ST $90^{\mathrm{T}}$ also reacted with several proteins from $D$. kuznetsovii, but this organism had 
TABLE 2. Sequence similarity matrix for members of the genus Desulfotomaculum and related taxa

\begin{tabular}{|c|c|c|c|c|c|c|c|c|c|c|c|c|c|c|}
\hline \multirow[b]{2}{*}{ Organism } & \multicolumn{14}{|c|}{$\%$ Sequence similarity } \\
\hline & 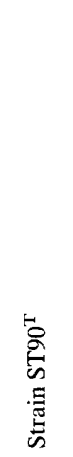 & 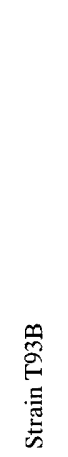 & 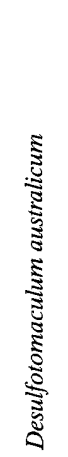 & 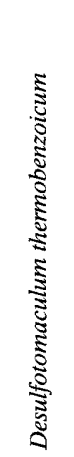 & 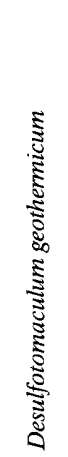 & 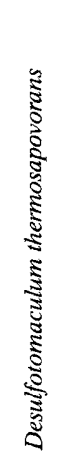 & 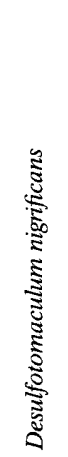 & 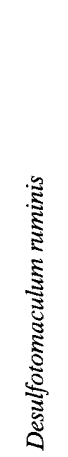 & 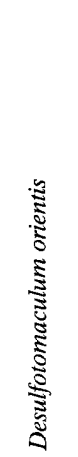 & 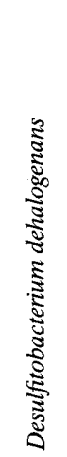 & 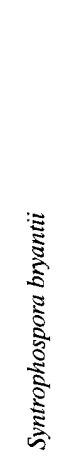 & 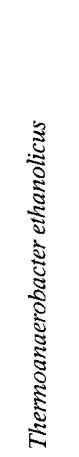 & 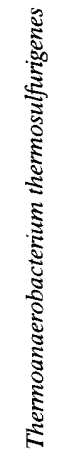 & 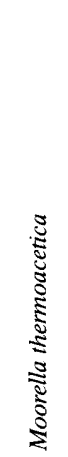 \\
\hline Strain T93B & 99.9 & & & & & & & & & & & & & \\
\hline Desulfotomaculum australicum & 98.6 & 98.5 & & & & & & & & & & & & \\
\hline Desulfotomaculum thermobenzoicum & 94.1 & 94.0 & 93.6 & & & & & & & & & & & \\
\hline Desulfotomaculum geothermicum & 89.1 & 89.0 & 88.7 & 89.0 & & & & & & & & & & \\
\hline Desulfotomaculum thermosapovorans & 88.6 & 88.5 & 88.3 & 88.2 & 93.1 & & & & & & & & & \\
\hline Desulfotomaculum nigrificans & 86.3 & 86.2 & 85.7 & 86.5 & 86.8 & 86.3 & & & & & & & & \\
\hline Desulfotomaculum ruminis & 85.3 & 85.2 & 84.7 & 84.5 & 86.6 & 86.2 & 91.1 & & & & & & & \\
\hline Desulfotomaculum orientis & 86.5 & 86.4 & 85.9 & 84.8 & 87.1 & 86.2 & 84.4 & 84.9 & & & & & & \\
\hline Desulfitobacterium dehalogenans & 86.0 & 85.9 & 85.4 & 84.9 & 87.3 & 86.2 & 85.3 & 86.1 & 93.9 & & & & & \\
\hline Syntrophospora bryantii & 85.2 & 85.1 & 84.8 & 84.1 & 82.0 & 81.4 & 81.9 & 82.0 & 84.9 & 83.9 & & & & \\
\hline Thermoanaerobacter ethanolicus & 86.6 & 86.5 & 86.1 & 85.6 & 85.1 & 84.2 & 83.1 & 82.8 & 85.0 & 84.1 & 85.2 & & & \\
\hline Thermoanaerobacterium thermosulfurigenes & 83.7 & 83.6 & 83.3 & 83.9 & 83.6 & 82.7 & 81.3 & 80.7 & 82.7 & 82.6 & 83.6 & 86.0 & & \\
\hline Moorella thermoacetica & 88.1 & 88.0 & 87.8 & 88.2 & 87.0 & 87.0 & 85.2 & 83.3 & 86.5 & 85.6 & 85.6 & 87.5 & 86.7 & \\
\hline Megasphaera elsdenii & 81.0 & 80.9 & 80.6 & 80.3 & 82.3 & 81.4 & 81.2 & 82.0 & 82.9 & 81.8 & 79.6 & 81.2 & 81.4 & 83.6 \\
\hline
\end{tabular}

only one antigen band (at a molecular weight of 41,000) in common with strain $\mathrm{ST} 90^{\mathrm{T}}$. All of the Desulfotomaculum strains examined contained a strong antigen that had a molecular weight of 33,000 .

Phylogenetic analysis and $\mathrm{G}+\mathrm{C}$ content. On the basis of $16 \mathrm{~S}$ rDNA similarity values (Table 2), strain ST90 falls within the radiation of the genus Desulfotomaculum and is most closely related to $D$. australicum and $D$. thermobenzoicum. Strain T93B, a thermophilic Desulfotomaculum strain that also was isolated from North Sea oil field water (38), exhibited $99.9 \%$ homology with strain ST90 ${ }^{\mathrm{T}}$. Figure 2 is a phylogenetic dendrogram generated from the matrix in Table 2 and shows the relationship of strains $\mathrm{ST}^{\mathrm{T}}$ and T93B to other Desulfotomaculum species.

The $\mathrm{G}+\mathrm{C}$ content of the DNA of strain ST90 ${ }^{\mathrm{T}}$ was $56 \mathrm{~mol} \%$ as determined by the chemical method and $57 \mathrm{~mol} \%$ as determined by the thermal denaturation method.

\section{DISCUSSION}

On the basis of phenotypic characteristics (i.e., dissimilatory sulfate reduction to sulfide, gram-positive cell wall structure, and formation of endospores), strain $\mathrm{ST} 90^{\mathrm{T}}$ was identified as a member of the genus Desulfotomaculum. Furthermore, our $16 \mathrm{~S}$ rDNA analysis revealed that strain $\mathrm{ST} 90^{\mathrm{T}}$ was most closely related to $D$. australicum (level of sequence similarity, 98.6\%). However, 16S rDNA sequence analysis is not suitable for distinguishing closely related species (i.e., species that exhibit levels of $16 \mathrm{~S}$ rDNA similarity of $97 \%$ or more) (44). According to Stackebrandt and Goebel (44), it is the differences in phenotypic properties among strains that should be the decisive factor when species are described.

Previously described guidelines suggest that $5 \mathrm{~mol} \%$ is the maximum range for $\mathrm{G}+\mathrm{C}$ contents that is permissible for a species (25). Strain $\mathrm{ST} 90^{\mathrm{T}}$ has a $\mathrm{G}+\mathrm{C}$ content of $57 \mathrm{~mol} \%$ as determined by thermal denaturation, whereas $D$. australicum has a $\mathrm{G}+\mathrm{C}$ content of $48 \mathrm{~mol} \%$ (Table 1 ). This difference alone is enough to warrant classification of strain $\mathrm{ST} 90^{\mathrm{T}}$ as a member of a separate species. In addition, significant differ-

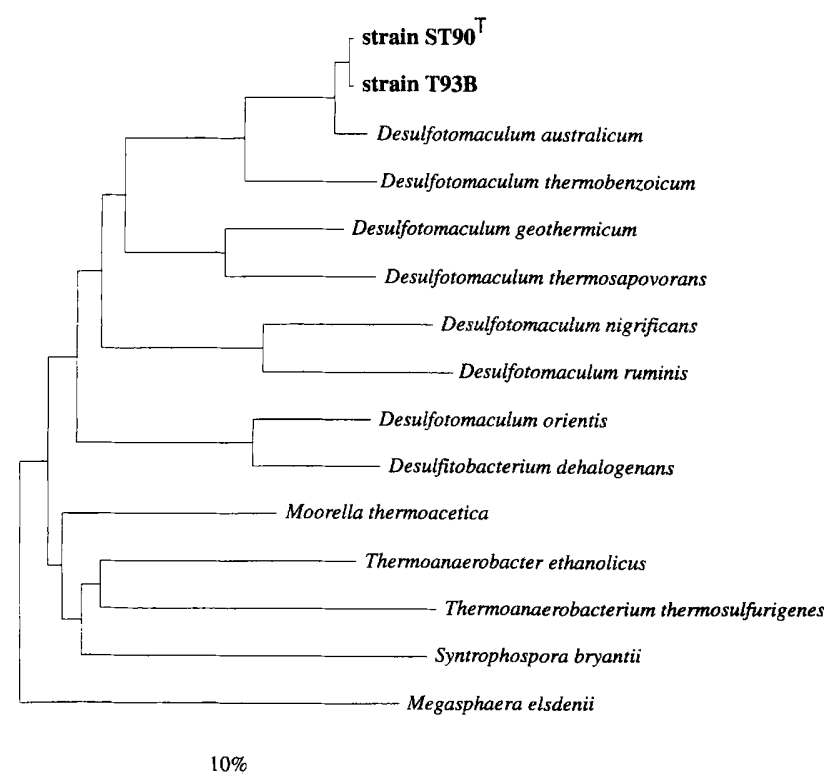

FIG. 2. Phylogenetic dendrogram based on 16S rDNA sequence comparison, showing the positions of strains $\mathrm{ST} 90^{\mathrm{T}}$ and $\mathrm{T} 93 \mathrm{~B}$ within the radiation of members of the genus Desulfotomaculum and related taxa. Bar $=10$ nucleotide changes per 100 nucleotides. 
ences in substrate utilization patterns, temperature optima, $\mathrm{pH}$ ranges (Table 1), and antigen patterns support this conclusion.

The 16S rDNA analysis revealed that the level of similarity between $D$. thermobenzoicum and strain $\mathrm{ST} 90^{\mathrm{T}}$ was $94.1 \%$; this, together with phenotypic differences (Table 1), showed that strain $\mathrm{ST} 90^{\mathrm{T}}$ is not a member of $D$. thermobenzoicum.

The protein profile of strain $\mathrm{ST} 90^{\mathrm{T}}$ is quite different from that of $D$. kuznetsovii. Together with physiological and genetic differences (Table 1), this shows that strain $\mathrm{ST} 90^{\mathrm{T}}$ is not closely related to D. kuznetsovii. Strain ST90 ${ }^{\mathrm{T}}$ can quickly be identified and distinguished from $D$. thermobenzoicum, D. australicum, and $D$. kuznetsovii by using immunoblotting.

Rosnes et al. (39) isolated two thermophilic Desulfotomaculum strains (strains T93B and T90A) from formation water that originated from the Statfjord oil field in the North Sea. During some of the growth experiments, strain T90A cultures were contaminated by strain T93B. Therefore, some of the growth characteristics of strain T90A (39) are incorrect, and this strain is considered lost. Our 16S rDNA analysis revealed that the level of similarity between strains T93B and ST $90^{\mathrm{T}}$ was $99.9 \%$. However, because of differences in $\mathrm{G}+\mathrm{C}$ contents and phenotypic characteristics (Table 1), these strains do not belong to the same species. Strain T93B should be assigned to the taxon D. australicum. Differences in phenotypic characteristics can be used to distinguish strain T93B and the type strain of this species.

Strain ST $90^{\mathrm{T}}$ was isolated from produced oil reservoir water obtained before breakthrough of injected seawater. Therefore, we concluded that it did not originate from injected seawater. Introduction of microorganisms into the Statfjord reservoir during drilling of production wells has been discussed by Rosnes et al. (39). These authors concluded that drilling operations could not be a source of contamination of formation water from this reservoir. Consequently, the most probable origin of strain $\mathrm{ST} 90^{\mathrm{T}}$ is the formation water itself.

It has been shown that Desulfotomaculum sp. strain T93B grows at $80^{\circ} \mathrm{C}$ and $30 \mathrm{MPa}$ (i.e., conditions that are representative of large parts of North Sea oil reservoirs) (38). The presence of heat-resistant endospores would allow Desulfotomaculum strains to survive for a long time in reservoirs with temperatures higher than the maximum growth temperatures of these organisms. In many unexplored North Sea oil reservoirs, such as the Statfjord reservoir, the concentration of sulfate is constantly low. In the absence of an electron acceptor, strain ST90 ${ }^{\mathrm{T}}$ is able to ferment pyruvate. However, pyruvate has not been found in formation waters from North Sea oil reservoirs. $M$. thermolithotrophicus was recently isolated from produced Statfjord reservoir water (31). The ability of strain ST $90^{T}$ to grow syntrophically with this hydrogenotrophic methanogen indicates that this may be one way that Desulfotomaculum strains grow in unexplored North Sea oil field reservoirs. Syntrophic growth of mesophilic propionate-degrading sulfate reducers and $\mathrm{H}_{2}$-utilizing methanogens has been described previously $(17,57)$, and such growth gives these organisms an ecological advantage in systems where sulfate is intermittently available (33). The ability to grow syntrophically could be a successful survival strategy used by sulfate reducers that inhabit ecological niches where the sulfate concentration is always low.

Description of Desulfotomaculum thermocisternum sp. nov. Desulfotomaculum thermocisternum (ther.mo.cis.ter'num. Gr. adj. thermos, hot; L. fem. n. cisterna, reservoir; N. L. adj. thermocisternum, hot reservoir, referring to the original habitat of the organism). Straight rods that occur singly and in chains and are 0.7 to $1.0 \mu \mathrm{m}$ in diameter and 2.0 to $5.2 \mu \mathrm{m}$ long. Cells of different sizes can occur in the same chain. Cells have peritri- chous flagella. Spores are spherical and central and distend the cells. No gas vacuoles are observed. The following substrates are utilized as carbon and energy sources in the presence of sulfate: $\mathrm{H}_{2}-\mathrm{CO}_{2}$, lactate, pyruvate, propionate, butyrate, pentanoate, hexanoate, heptanoate, octanoate, nonanoate, decanoate, tetradecanoate, pentadecanoate, hexadecanoate, heptadecanoate, ethanol, propanol, and butanol. Lactate is incompletely oxidized to acetate. The organism grows fermentatively on pyruvate. In the absence of sulfate it also grows on propionate in coculture with a hydrogenotrophic methanogen. Sulfate, sulfite, and thiosulfate are utilized as electron acceptors. Biotin is required as a growth factor. The temperature range for growth is 41 to $75^{\circ} \mathrm{C}$; the optimum temperature is $62^{\circ} \mathrm{C}$. The $\mathrm{pH}$ range for growth is 6.2 to 8.9 ; the optimum $\mathrm{pH}$ is 6.7 . The $\mathrm{NaCl}$ concentration range for growth is $17 \mu \mathrm{M}$ to $800 \mathrm{mM}$; the $\mathrm{NaCl}$ optimum concentration is 50 to $200 \mathrm{mM}$. The $\mathrm{G}+\mathrm{C}$ content of the DNA is $56 \mathrm{~mol} \%$ as determined by HPLC and $57 \mathrm{~mol} \%$ as determined by thermal denaturation.

Isolated from pure formation water that originated from the subterranean Brent Group oil formation $2.6 \mathrm{~km}$ below the sea floor in the Norwegian sector of the North Sea. The type strain is strain ST90 (= DSM 10259).

\section{ACKNOWLEDGMENTS}

Financial support from the Norwegian oil company Statoil is gratefully acknowledged.

We thank Statoil and especially Egil Sunde for contributing samples and information. We also thank Bente E. Thorbjørnsen for technical assistance and B. K. C. Patel for providing D. thermobenzoicum TSB and D. australicum $\mathrm{AB} 33$.

\section{REFERENCES}

1. Antloga, K. M., and W. M. Griffin. 1985. Characterization of sulfate-reducing bacteria isolated from oilfield waters. Dev. Ind. Microbiol. 26:597-610.

2. Barth, T., and M. Riis. 1992. Interactions between organic acid anions in formation waters and reservoir mineral phases. Org. Geochem. 19:455-482.

3. Beeder, J., R. K. Nilsen, J. T. Rosnes, T. Torsvik, and T. Lien. 1994. Archaeoglobus fulgidus isolated from hot North Sea oil field waters. Appl. Environ. Microbiol. 60:1227-1231.

4. Beeder, J., T. Torsvik, and T. Lien. 1995. Thermodesulforhabdus norvegicus, gen. nov., sp. nov., a novel thermophilic sulfate-reducing bacterium from oil field water. Arch. Microbiol. 164:331-336.

5. Borgund, A. E., and T. Barth. 1994. Generation of short-chained organic acids from crude oil by hydrous pyrolysis. Org. Geochem. 21:943-952.

6. Burnette, W. N. 1981. "Western blotting": electrophoretic transfer of proteins from sodium dodecyl sulfate-polyacrylamide gels to unmodified nitrocellulose and radiographic detection with antibody and radioiodinated protein A. Anal. Biochem. 112:195-203.

7. Campbell, L. L., and J. R. Postgate. 1965. Classification of the spore-forming sulfate-reducing bacteria. Bacteriol. Rev. 29:359-363.

8. Christensen, B., T. Torsvik, and T. Lien. 1992. Immunomagnetic captured thermophilic sulfate-reducing bacteria from North Sea oil field waters. Appl. Environ. Microbiol. 58:1244-1248.

9. Cochrane, W. J., P. S. Jones, P. F. Sanders, D. M. Holt, and M. J. Mosley. 1988. Studies on the thermophilic sulfate-reducing bacteria from a souring North sea oil field. Soc. Petrol. Eng. SPE 18368:301-316.

10. Cord-Ruwisch, R. 1985. A quick method for the determination of dissolved and precipitated sulfides in cultures of sulfate reducing bacteria. J. Microbiol. Methods 4:33-36.

11. Cord-Ruwisch, R., W. Kleinitz, and F. Widdel. 1987. Sulfate-reducing bacteria and their activities in oil production. J. Petrol. Technol. 1:97-106.

12. Cunningham, A. B., E. J. Bouwer, and W. G. Characklis. 1990. Biofilms in porous media, p. 697-732. In W. G. Characklis and K. C. Marshall (ed.), Biofilms. Wiley, New York.

13. Daumas, S., R. Cord-Ruwisch, and J. L. Garcia. 1988. Desulfotomaculum geothermicum sp. nov., a thermophilic, fatty acid-degrading, sulfate-reducing bacterium isolated with $\mathbf{H}_{2}$ from geothermal ground water. Antonie Leeuwenhoek 54:165-178.

14. De Ley, J. 1970. Reexamination of the association between melting point, buoyant density, and chemical base composition of deoxyribonucleic acid. J. Bacteriol. 101:738-754

15. DeSoete, G. 1983. A least squares algorithm for fitting additive trees to proximity data. Psychometrica 48:621-626.

16. Fardeau, M.-L., B. Ollivier, B. K. C. Patel, P. Dwivedi, M. Ragot, and J.-L. 
Garcia. 1995. Isolation and characterization of a thermophilic sulfate-reducing bacterium, Desulfotomaculum thermosapovorans sp. nov. Int. J. Syst. Bacteriol. 45:218-221

17. Heppner, B., G. Zellner, and H. Diekmann. 1992. Start-up and operation of a propionate-degrading fluidized-bed reactor. Appl. Microbiol. Biotechnol. 36:810-816.

18. Isaksen, M. F., F. Bak, and B. B. Jørgensen. 1994. Thermophilic sulfatereducing bacteria in cold marine sediment. FEMS Microbiol. Ecol. 14:1-8.

19. Jukes, T. H., and C. R. Cantor. 1969. Evolution of protein molecules, p. 21-132. In H. N. Munro (ed.), Mammalian protein metabolism. Academic Press, New York.

20. Karnauchow, T. M., S. F. Koval, and K. F. Jarrell. 1992. Isolation and characterization of three thermophilic anaerobes from a St. Lucia hot spring. Syst. Appl. Microbiol. 15:296-310.

21. Kilburn, K. H. 1993. Case report: profound neurobehavorial deficits in an oil field worker overcome by hydrogen sulfide. Am. J. Med. Sci. 306:301-305.

22. Klemps, R., H. Cympionka, F. Widdel, and N. Pfennig. 1985. Growth with hydrogen, and further physiological characteristics of Desulfotomaculum species. Arch. Microbiol. 143:203-208.

23. Laemmli, U. K. 1970. Cleavage of structural proteins during the assembly of the head of bacteriophage T4. Nature (London) 227:680-685.

24. Lewan, M. D., and J. B. Fisher. 1994. Organic acids from petroleum source rocks, p. 70-114. In E. D. Pittman and M. D. Lewan (ed.), Organic acids in geological processes. Springer-Verlag, Berlin.

25. Logan, N. A. 1994. Bacterial systematics. Blackwell Scientific Publication, Oxford.

26. Love, C. A., B. K. C. Patel, P. D. Nichols, and E. Stackebrandt. 1993. Desulfotomaculum australicum sp. nov., a thermophilic sulfate-reducing bacterium isolated from the Great Artesian Basin of Australia. Syst. Appl. Microbiol. 16:244-251.

27. Mesbah, M., U. Premachandran, and W. Whitman. 1989. Precise measurement of the $\mathrm{G}+\mathrm{C}$ content of deoxyribonucleic acid by high-performance liquid chromatography. Int. J. Syst. Bacteriol. 39:159-167.

28. Min, H., and S. H. Zinder. 1990. Isolation and characterization of a thermophilic sulfate-reducing bacterium, Desulfotomaculum thermoacetoxidans sp. nov. Arch. Microbiol. 153:399-404.

29. Nazina, T. N., A. E. Ivanova, L. P. Kanchaveli, and E. P. Rozanova. 1987. A new sporeforming thermophilic methylothrophic bacterium, Desulfotomaculum kuznetsovii sp. nov. Microbiology (Engl. Transl. Mikrobiologiya) 57: $659-663$.

30. Nazina, T. N., and E. P. Rozanova. 1977. Thermophilic sulfate reducing bacterium from oil strata. Microbiology (Engl. Transl. Mikrobiologiya) 47: 773-778.

31. Nilsen, R. K., and T. Torsvik. 1996. Methanococcus thermolithotrophicus isolated from North Sea oil field reservoir water. Appl. Environ. Microbiol 62:728-731.

32. Odom, J. M. 1993. Industrial and environmental activities of sulfate-reducing bacteria, p. 189-210. In J. M. Odom and R. Singleton, Jr. (ed.), The sulfatereducing bacteria: contemporary perspectives. Springer-Verlag, New York.

33. Oude Elferink, S. J. W. H., A. Visser, L. W. Hulshoff Pol, and A. J. M. Stams. 1994. Sulfate reduction in methanogenic bioreactors. FEMS Microbiol. Rev. 15:119-136.

34. Pfennig, N. 1978. Rhodocyceus purpurus gen. nov, and sp. nov., a ring-shaped, vitamin $\mathrm{B}_{12}$-requiring member of the family Rhodospirillaceae. Int. J. Syst. Bacteriol. 28:283-288.

35. Postgate, J. R. 1984. The sulfate-reducing bacteria, 2nd ed. Cambridge University Press, Cambridge.

36. Rainey, F. A., M. Dorsch, H. W. Morgan, and E. Stackebrandt. 1992. 16S rDNA analysis of Spirochaeta thermophila: position and implications for the systematics of the order Spirochaetales. Syst. Appl. Microbiol. 16:224-226.

37. Rees, G. N., G. S. Grassia, A. J. Sheeny, P. P. Dwivedi, and B. K. C. Patel. 1995. Desulfacinum infernum gen. nov., sp. nov., a thermophilic sulfate-reducing bacterium from a petroleum reservoir. Int. J. Syst. Bacteriol. 45:85-89.
38. Rosnes, J. T., A. Graue, and T. Lien. 1991. Activity of sulfate-reducing bacteria under simulated reservoir conditions. Soc. Petrol. Eng. SPE 19429: 217-220.

39. Rosnes, J. T., T. Torsvik, and T. Lien. 1991. Spore-forming thermophilic sulfate-reducing bacteria isolated from North Sea oil field waters. Appl. Environ. Microbiol. 57:2302-2307.

40. Rozanova, E. P., and T. A. Pirovanova. 1986. Reclassification of $D$. thermophilus (Rozanova and Khudyakova 1974). Microbiology (Engl. Transl. Mikrobiologiya) 57:85-89.

41. Silhavy, T. J., M. L. Berman, and L. W. Enquist. 1984. Procedure 25. DNA extraction from bacterial cells, p. 137-139. In Experiments with gene fusions. Cold Spring Harbor Laboratory, Cold Spring Harbor, N.Y.

42. Silhavy, T. J., M. L. Berman, and L. W. Enquist. 1984. Procedure 40. Phenol/chloroform extraction of DNA samples, p. 177-179. In Experiments with gene fusions. Cold Spring Harbor Laboratory, Cold Spring Harbor, N.Y.

43. Spurr, A. R. 1969. A low viscosity epoxy resin embedding medium for electron microscopy. J. Ultrastruct. Res. 26:31-43.

44. Stackebrandt, E., and B. M. Goebel. 1994. Taxonomic note: a place for DNA-DNA reassociation and $16 \mathrm{~S}$ rRNA sequence analysis in the present species definition in bacteriology. Int. J. Syst. Bacteriol. 44:846-849.

45. Stetter, K. O., R. Huber, E. Blöchl, M. Kurr, R. D. Eden, M. Fielder, H. Cash, and I. Vance. 1993. Hyperthermophilic archaea are thriving in deep North Sea and Alaskan oil reservoirs. Nature (London) 365:743-745.

46. Tamaoka, J., and K. Komagata. 1984. Determination of DNA base composition by reversed-phase high-performance liquid chromatography. FEMS Microbiol. Lett. 25:125-128.

47. Tanimoto, Y., and F. Bak. 1994. Anaerobic degradation of methylmercaptan and dimethyl sulfide by newly isolated thermophilic sulfate-reducing bacteria. Appl. Environ. Microbiol. 60:2450-2455.

48. Tasaki, M., Y. Kamagata, K. Nakamura, and E. Mikami. 1991. Isolation and characterization of a thermophilic benzoate-degrading, sulfate-reducing bacterium, Desulfotomaculum thermobenzoicum sp. nov. Arch. Microbiol. 155: 348-352.

49. Tvedt, B., K. Skyberg, O. Aaserud, A.. Hobbesland, and T. Mathisen. 1991. Brain damage caused by hydrogen sulfide: a follow-up study of six patients. Am. J. Ind. Med. 20:91-101.

50. Visuvanathan, S., M. T. Moss, J. L. Stanford, J. Hermon-Taylor, and J. J. McFadden. 1989. Simple enzymatic method for the isolation of DNA from diverse bacteria. J. Microbiol. Methods 10:59-64.

51. Walther-Mauruschat, A., M. Aragno, F. Mayer, and H. G. Schlegel. 1977. Micromorphology of Gram-negative hydrogen bacteria. II. Cell envelope, membranes, and cytoplasmatic inclusions. Arch. Microbiol. 114:101-110.

52. Werkmann, C. H., and H. J. Weaver. 1927. Studies in the bacteriology of sulphur stinkers spoilage of canned sweet corn. Iowa State Coll. J. Sci. 2: 57-67.

53. Widdel, F., G. W. Kohring, and F. Mayer. 1983. Studies of dissimilatory sulfate-reducing bacteria that decompose fatty acids. III. Characterization of the filamentous gliding Desulfonema limicola gen. nov. and sp. nov. and Desulfonema magnum sp. nov. Arch. Microbiol. 134:286-294.

54. Widdel, F., and N. Pfennig. 1981. Studies of dissimilatory sulfate-reducing bacteria that decompose fatty acids. I. Isolation of sulfate-reducing bacteria enriched with acetate from saline environments. Description of Desulfobacter postgatei gen. nov. and sp. nov. Arch. Microbiol. 129:395-400.

55. Widdel, F., and N. Pfennig. 1984. Dissimilatory sulfate- and sulfur-reducing bacteria, p. 663-679. In N. R. Krieg and J. G. Holt (ed.), Bergey's manual of systematic bacteriology, vol. 1. The Williams \& Wilkins Co., Baltimore.

56. Wolin, E. A., M. J. Wolin, and R. S. Wolfe. 1963. Formation of methane by bacterial extracts. J. Biol. Chem. 238:2882-2886.

57. Wu, W. M., M. K. Jain, E. Conway de Macario, J. H. Thiele, and J. G. Zeikus. 1992. Microbial composition and characterization of prevalent methanogens and acetogens isolated from syntrophic methanogenic granules. Appl. Microbiol. Biotechnol. 38:282-290. 